\title{
METAMORFOSIS BARROCAS
}

\author{
Fernando Lázaro Carreter \\ De la Real Academia Española
}

En el capítulo L de la primera parte del Quijote, recordémoslo, el hidalgo contradice al Canónigo, que le ha reprochado su afición a los libros de caballerías. Exaltado, elogia el mérito de tales libros, alegando el gusto que proporciona su lectura. Invitan, por ejemplo, a ver con la imaginación un gran lago de pez hirviente, del cual sale una voz exhortando a un caballero que lo contempla a zambullirse en él para admirar las maravillas del fondo. Cuando el caballero accede, dice el manchego, se halla entre unos floridos campos más hermosos que los Elíseos. «Allí le parece que el cielo es más transparente, y que el sol luce con claridad más nueva: ofrécesele a los ojos una apacible floresta de tan verdes y frondosos árboles compuesta, que alegra a la visla su verdura, y entretiene los ó́dos el dulce y no aprendido canto de los infinitos y pintados pajarillos que por los intrincados ramos van cruzando». Prosigue esta descripción de un paisaje arcádico que el caballero sumergido recorre hasta dar con dos fuentes. Una es «de jaspe variado», es decir, polícromo, «y de liso mármol compuesta»; ve otra "a lo brutesco ordenada, donde las menudas conchas de las almejas con las torcidas casas blancas y amarillas del caracol, puestas con orden desordenada, mezclados entre ellas pedazos de cristal luciente y de contrahechas esmeraldas, hacen una variada labor, de manera que el arte, imitando a la naturaleza, parece que allí la vence».

Discutiendo la etimología del vocablo barroco, y en favor de que fuera el nombre de la perla así llamada en portugués, y también de la roca desgajada y sumamente irregular, el profesor Bodini adujo ese pasaje cervantino, viendo en ellas dos símbolos. La primera fuente, decía «è quella del rinascimento; l'altra del barocco... L'alternativa, e la correspondenza, sono perfette: da una parte una superficie levigata, dall'altra una superficie ruvida, accidentata. Da una parte, la squisita elaborazione 'artistica', dell'altra il rozzo, il 
grotesco»" '. De esa manera, don Quijote pondría en un plano igual de aprecio estético las reproducciones estilizada y la abusiva y desmesurada de la realidad.

Es poco probable que el propio Cervantes experimentara una complacencia igual ante ambas fuentes. Esa igualdad se produce en la mente de un loco, y en un pasaje en que éste proclama las bondades de los libros de caballerías. Hemos de pensar, más bien, que se trata de una equiparación irónica: de las dos se burla. De la primera, «artificiosa» en medio de la floresta artificiosa, porque lo natural jamás se manifiesta tan relamido; de la segunda, porque se excede en desorden.

Pero, cualquiera que sea su intención, ese pasaje alude inequívocamente a dos estéticas concurrentes en la época, y Cervantes ha acertado a señalar bien los caracteres esenciales de la barroca: el orden desordenado y, sobre todo, el hecho de que, al imitar, el arte vence a la Naturaleza, la sobrepasa, va más allá,

Eran las dos líneas que, procedentes del Renacimiento, venían a confluir en ese cruce de siglos; una, la que estiliza en busca de la gracia delicada, y que, en la pintura, tras Correggio y Rafael, culmina con El Greco; otra, que, por el contrario exhibe esfuerzo y suntuosidad, gigantismo y hasta violencia, que Weisbach denominó «estilo heroico», representada esencialmente por Miguel Ángel ${ }^{2}$. Es esta línea «heroica» la que va a triunfar en el seiscientos, hasta el punto de que el autor de la Capilla Sixtina se le ha llamado alguna vez «padre del Barroco».

No es casual que a los poemas de amplio aliento y profusa ornamentación se les denomine heroicos. Vázquez Siruela, asegura de Góngora que «después de larga y profunda meditación, rompió los canceles que él mismo se había impuesto, y salió con aquellos partos heroicos que, como admiraron a unos, ansí en otros causaron notable turbación» ${ }^{3}$. Los partos así calificados eran, obviamente, las Soledades y el Polifemo. Y no deja de ser el cíclope una criatura miguelangelesca, con su volumen corporal atlético, con su gesticulación desmesurada, con su impetuosidad y violencia.

Pero es claro que el "heroísmo» de nuestros escritores sescentistas, de esos extensos poemas llamados heroicos, no sale de aquel gran artista plástico, sino de la literatura argéntea latina, cuyo influjo sustituye en el siglo XVII al de la época de Augusto, dominante en el XVI. Un memorable trabajo del gran latinista italiano Ettore Paratore publicado hace cerca de treinta años ${ }^{4}$, estudiaba atentamente el fenómeno, con especial atención a la presencia de Ovidio y de Apulcyo en las letras curopcas: Marino, Valle, cl drama pastoral, el melodrama, los emblemas, Shakespeare, los dramaturgos isabelinos, Racine y, por supuesto, la picaresca, Góngora, Quevedo y Gracián.

Traza Paratore un paralelo de la sociedad de finales del XVI y del XVII con la de Roma en tiempos de Ovidio; entre las concomitancias que señala, destaca el hecho de que toda la vida cultural europea se desarrolla también monopolizada, ahora por las monarquías europeas (en el caso de Holanda, por la aristocracia mercantil). Monarquías que han reducido la nobleza a la condición de corte de honor del rey, apabullándola,

1.- Manierismo, Barocco, Rococò: Concetti e Termini, Roma, Accademia Nazionale dei Lincei, 1962, pág. 53.

2.- Manierismus und mittelalterlicher Kunst, Basilea, 1942, pág. 165 y ss.

3.- Apud M. Artigas, Don Luis de Góngora y Argote, Madrid, 1925, pág. 384.

4.- «L'influenza della letteratura latina da Ovidio ad Apuleyo nell'età del Manierismo e del Barocco», en el vol. cit. en la nota 1, pág. 239 y ss. 


\section{METAMORFOSIS BARROCAS}

diríamos, con una escenografía opulenta que hace mayor la majestad del monarca. Y ello, igual en Versalles que en Madrid, en los palacios centroeuropeos o en los ingleses de los Estuardo. Los nobles, a su vez, para mostrarse dignos de la monarquía, se rodean de lujos similares. Paralelamente, la Iglesia entra en esa pugna de esplendor, con la que se haga patente su supremacía sobre el poder civil. La ostentación como ideal va a ser causa activa en el desarrollo y esplendor del Barroco, en la invención de sus formas expresivas más características, en su teatralidad, en las apoteosis de su ornamentación.

Los artistas, o sirven estos designios o los asumen como inevitable rasgo distintivo de la época. La grandiosidad, la desmesura «heroica», se les impone. Nada más conveniente para expresarlas que un monumental o complejo alarde en las formas; $y$, entre los temas, la Mitología ofrece un muestrario argumental deslumbrante. Otros temas, como el sacro, el histórico o el que exalta reyes e ilustres señores, se mitologizan para dotarlos de grandeza. A veces, próceres son representados como deidades paganas 5; y a lòs santos se les otorga prestancia corporal y gesticulación olímpicas. Las Metamorfosis ovidianas ofrecían un inagotable elenco de posibilidades, tanto para las formas como para los argumentos.

De ahí ese supremo influjo del poema en la edad barroca europea. Pero no olvidemos que muchos de los ejecutores de toda esa aparatosa escenografía eran artistas dotados de un personal sentido crítico, que si, por un lado, se sometían a los cánones estéticos del tiempo, por otro, consideraban su radical falsedad. De ahí sus frecuentes contradicciones.

Muchos artistas barrocos se vengan, diríamos, de su sumisión a una estética que no pueden soslayar, mediante el expediente de afrontarla irónicamente, y, en ocasiones, sarcásticamente. Por un lado, vencen a la Naturaleza con sus artificios, para usar los términos cervantinos; pero, por otro, la introducen solapada o explícitamente, en sus manifestaciones menos nobles. Pensemos en el tratamiento plástico de los mitos por un Rubens, que presenta como fastuosas mascaradas las hazañas de los dioses; en un Velá7quez que los rebaja a jayanes de barrio. Y cuando esto no es posible, por tratarse de temas sacros, en un Murillo, pasando de sus triunfales Inmaculadas a la patética representación de la miseria infantil. En la literatura, esa "venganza» contra la evasión magnificente determina la injerencia en el drama isabelino o en la comedia española, de toscos criados que se entrometen en las acciones más elevadas con su ruda vulgaridad; o el auge barroco de la novela picaresca, en competencia con las ficciones idealizadoras. Y, por supuesto - volvemos siempre a los mismos-, en la contradictoria creación de Góngora, Quevedo y Gracián. Pero también de muchos otros poetas y prosistas menores.

Jean Rousset, en su famoso libro La littérature de l'âge baroque en France (1953), señaló como rasgos característicos del Barroco estos cuatro: la inestabilidad o ruptura del equilibrio, la movilidad, las metamorfosis y el predominio de los elementos decorativos. E hizo notar que la disposición de los espíritus a tales rasgos del arte determinó la acogida triunfal que Europa dispensó a Ovidio, hasta el punto de ser el XVII la verdadera «aetas ovidiana». El citado Ettore Paratore, profundizando en el estudio de aquel influjo, afirma que «la más reciente literatura crítica obliga a considerarlo como uno de los principales componentes formadores del gran episodio cultural que constituyen el gusto manierista y barroco».

Él mismo señaló presencias ovidianas en nuestra literatura tan curiosas y se diría tan

5.- Por ejemplo, en el frontispicio de El Fernando (1632), de Juan Antonio de Vera, Olivares aparece en figura de Atlas sosteniendo el globo terráqueo. 


\section{FERNANDO LÁZARO CARRETER}

inesperadas, como la de haber sido un pasaje de las Metamorfosis, el de Alción (l. XI), el inspirador de la letrilla «La más bella niña de nuestro lugar». $O$ el hecho de haber sugerido Séneca - otro escritor de la Edad de Plata latina-, juntamente con el Sulmonense, el famoso verso «infame turba de nocturnas aves». O que el soneto celebérrimo «La dulce boca que a gustar convida» reelabore temas ovidianos procedentes de los mitos de Orfeo, Aurora y Céfalo.

Puedo añadir que aquel gran poeta asoma su faz donde menos podía sospecharse. Recuérdese cómo a Pablos de Segovia lo llama un compañero de escuela «hijo de una puta y hechicera»; a raíz de lo cual, dice, «roguéla (a mi madre) que me declarase si le podía desmentir con verdad; o que me dijese si me había concebido a escote entre muchos o si era hijo de mi padre» $(I, 2)$. ¿No podría asegurarse que esto lleva la inconfundible impronta quevedesca? Y es cierto; pero sólo en el chiste. Porque la situación, según creo, procede del episodio ovidiano de Faetón, cuando Épafo le asegura que no es hijo de Júpiter. Humillado y colérico, Faetón fue a su madre Clímene diciéndole: «Me averguienzo tanto de que se me hayan podido decir tales ultrajes como de no haber podido desmentirlos. Pero, si es verdad que he sido engendrado de estirpe celeste, dame una prueba de mi elevada cuna y demuestra que pertenezco al cielo» ${ }^{6}$.

El sentimiento de insatisfacción de los artistas con la estética grandilocuente que sirven es causa, hemos dicho, de la contienda entre la espectacularidad de los temas y de las formas, y el realismo o infrarrealismo que acontece en el Barroco. Ya hemos mencionado a artistas en quienes esa contradicción se manifiesta, y, entre ellos, a Quevedo. Ninguna de sus obras muestra mejor la actitud sescentista ante los mitos que su fantasía La hora de todos y Fortuna con seso. La dependencia que manifiesta de Ovidio es máxima. Como es sabido, las Metamorfosis comienzan exponiendo los orígenes del mundo, las distintas etapas que acontecieron hasta la aparición de los humanos, con lo que se inició la sucesión de las cuatro edades: la de oro, la de plata gobernada ya por Júpiter, la de bronce en que los hombres se inclinaron al uso de las armas, y, por fin, la de hierro, que vio aparecer las guerras, la traición y todos los males. "Se vive de la rapiña», dice el texto ovidiano; «ni un huésped puede tener seguridad de su huésped, ni un suegro de su yerno; incluso entre hermanos es rara la avenencia» (vs. 144-5). Al ver Júpiter tan ingente desorden, «ingemit», dio un gemido, y convocó la asamblea de los dioses. Ante ellos, pronuncia un discurso acusatorio contra la humanidad, y la condena a un diluvio universal. Serán únicos supervivientes del desastre, Deucalión y su esposa Pirra, que, interpretando un oráculo, van recogiendo piedras y arrojándolas a sus espaldas. Maravillosamente, los pedruscos fueron metamorfoseándose en hombres y mujeres. En los orígenes de la humanidad están, pues, ya los cambios, las transformaciones. El mundo quedó poblado, y aparecieron también los seres míticos a cuya prodigiosa historia de mutaciones, de tránsitos de lo sobrehumano a lo humano, o a lo vegetal o animal, se dedica este gran libro de los prodigios.

El cual, en aquella época para la que sólo resulta artísticamente fértil lo exagerado,

6.- Trad, de A. Ruiz de Elvira de los versos:

Pudet haec obprobria nobis et dici potuisse et non potuisse refelli; at tu, si modo sum caelesti stirpe creatus, ede notam tanti generis meque adsere caelo! (I, vs. 758-761).

Metamorfosis, Barcelona, Alma Mater, 1964, 1, pág. 38. 


\section{METAMORFOSIS BARROCAS}

convencida de que todo es transición, apariencia, inestabilidad, falsedad en suma, pasaba a constituirse en el modelo clásico por antonomasia, en la verdadera Biblia del Barroco. Menéndez Pidal acertó a señalar los versos de Argensola «porque ese cielo azul que todos vemos/ni es cielo ni es azul», como sintomático ante cualquier esplendor, su desconfianza ante lo que puede ser un engaño a los ojos, el cielo incluido.

Patente esa desconfianza a lo largo de nuestro siglo XVII, nadie la manifiesta tan constantemente como Francisco de Quevedo, de modo particularmente extremado en $L a$ hora de todos, construida sobre el cañamazo de las Metamorfosis. Su célebre arranque, con Júpiter encolerizado convocando a los dioses del Olimpo, no es sino una parodia de aquella reunión narrada por Ovidio a que acabo de referirme. Sólo que, claro es, vista con la burla que ya señalamos con que fueron contemplados muchas veces los mitos, no sin el ejemplo de otro gran texto inspirador de aquel siglo, la Apocoloquintosis de Séneca, con la curia de los dioses indignada al querer integrarse en ella el emperador Claudio, que es transformado en calabaza. E instigado Quevedo por su propio talante, y por la concepción desolada del hombre que recibía de Séneca y los estoicos.

No hace falta recordar cómo. Júpiter, en aquella congregación de dioses, a lo que castiga a los hombres y a las cosas es a ser transformados, pero no de lo que son a una apariencia nueva, sino de su apariencia a lo que son realmente: el médico en verdugo; el palacio en solar, tras desaparecer cuanto su dueño ha robado; las falsas mozas en viejas; los letrados en demandados; los tabcrncros cn aguadorcs...

Es una especie de rizar el rizo al rizo, éste de seguir el camino contrario a la magnificación embellecedora. Las primeras palabras de La hora de todos son para narrar la cólera de Júpiter, correspondiendo al «ingemit» de Ovidio: «Júpiter, hecho de hieles, se desgañitaba poniendo los gritos en la tierra; porque ponerlos en el cielo donde asiste no era encarecimiento a propósito" 7. La Mitología ovidiana, o se respeta con todo su boato, en las abundantes fábulas de la época estudiadas por José María de Cossío, o en los innumerables poemas, largos o breves, dedicados a los grandes mitos (Dafne y Apolo, Faetón, Ícaro, Eco y Narciso, Orfeo, Circe, etc.), o se sigue la vía opuesta a la de encarecer, mediante el sistema de bajar a la tierra los sucesos olímpicos, como hace Quevedo. Será la Mitología burlesca que él practica, y, antecediéndole, Góngora con su admirable Fábula de Píramo y Tisbe.

Este abatimiento de lo celeste, que, como he dicho, tiene precedentes en la literatura clásica, con Séneca como modelo inmediato, se corresponde también con la degradación de lo épico, que bastante antes había practicado Pulci, pero que ahora efectúa el mismo Cervantes, no solamente con don Quijote, sino que la extiende a figuras del Romancero, como Gaiferos y Melisendra, o de la épica italiana más prestigiosa, como Reinaldos de Montalbán, Orlando y Angélica. Quevedo se cebó también en algunos de ellos.

Exaltar o degradar son, como es natural, manifestaciones de una visión que no contempla el mundo y sus cosas como estables y bien logradas, sino en movimiento. Y el movimiento es cambio, transformación, metamorfosis. No hay perfección; Lupercio Argensola lo dirá hablando del mundo, «en el cual siempre es raro lo perfecto». Como dirá también que «tenemos la peor de las edades/agora que en los hijos de los hombres/se van disminuyendo las verdades» ${ }^{8}$. La perspectiva intelectual más constante sólo advierte

7.- Cito por Obras completas. Prosa, ed. L. Astrana Marín, Madrid, Aguilar, 1945, pág. 288.

8.- Rimas de Lupercio y' Bartolomé L. de Argensola, ed. José Manuel Blecua, Zaragoza, Institución «Fernando el Católico», I, 1950, págs. 77 y 89. 
imperfección y engaño. No hace falta ejemplificar algo tan obvio y tan observado; se siente vivir en el peor momento histórico de los hombres. De ahí que las grandezas a que el arte, según dijimos, tenga que consagrarse, reciban el correctivo de la burla, por la cual se insinúa en el Barroco la reticencia burguesa ante las desimesuras, y avanza decididamente el espíritu crítico que habrá de triunfar con la Ilustración.

Esa inestabilidad del mundo tiene su exponente más claro en el conceptismo, que consiste esencialmente en el vaivén de la mente para sorprender mutaciones o forzarlas, sometiendo al mismo esfuerzo a las inteligencias de oyentes y lectores. Ovidio había sido maestro en esa gimnástica del espíritu. Gracián, en trance de definir el concepto, ejemplificará con un mote ovidiano en que se lee: $O$, nix, flamma mea, 'Oh, nieve, llama mía', donde el nombre de una mujer, igual al de la piedra ónix, que permite aludir a la dureza indiferente de la cortesana hacia el poeta, se descompone en la interjección $o$ y el sustantivo nix, que significa 'nieve'. De Ónix, hemos de ir a la piedra, que representa la dureza de la cortesana con el poeta y, de ésta, a la nieve, esto es, a la frialdad con que corrcspondc al enamorado. Y, todavía, de aquí, con otro salto, a la llama, metáfora del ardor amatorio, con la cual se identifica la nieve en atrevida conjunción de contrarios. Son varios movimientos mentales, varios conceptos, contraídos en sólo cuatro palabras.

Partiendo de ellos, Gracián explicará: «Consiste, pues, este artificio conceptuoso en una primorosa concordancia, en una armónica correlación entre dos o tres cognoscibles extremos, expresada por un acto del entendimiento». Y aún afinárá más en la definición, acuñándola con esta fórmula, que es, sin duda, la más perfecta con que se ha caracterizado el concepto: «Es un acto del entendimiento que exprime la correspondencia que se halla entre los objetos" ${ }^{9}$.

No es, sin embargo, original. Por supuesto, la incitación espontánea a hallar parecidos, diferencias o contrastes entre cosas diversas, parece aneja al espíritu humano. Está por supuesto en la base de operaciones que van de la más elemental aptitud para comparar, hasta la más refinada capacidad de los poetas para forjar metáforas. Pero ha habido momentos históricos en que la exhibición de tales habilidades se convirtió en valor estético y gozó de máxima estima. En nuestra literatura, una de ellas fue el siglo XV; la otra, el período barroco. No hace falta recordar cómo Lope de Vega admiraba a poetas como Escrivá, Cartagena, Estúñiga o Juan de Mena, llamándolos «ingenios maravillosos» por su destreza en crear conceptos, y hasta no dudando en afirmar que alguno de ellos los alumbró «milagrosamente».

Será difícil establecer si a esta adopción del concepto como célula estilística fundamental de la creación literaria barroca se llegó por espontáneo devenir de nuestras letras, o si obedeció a influjo italiano. Porque también en Italia se produce desde fines del XVI una potenciación del arte de correspondencias, que tiene un definidor insigne: Giordano Bruno, al que diversos críticos, como Joseph A. Mazzeo y Giorgio Bàrberi Squarotti 10, señalan como el más lúcido propulsor del conceptismo italiano. Y bien sabido es cómo la teorización gracianesca depende estrechamente de la obra de Camillo Pellegrino Del concetto poetico (1598).

Cabe, quizá, pensar en una génesis simultánea inducida por causas comunes, entre

9.- Agudeza y' arte de ingenio, discurso II; ed. E. Correa Calderón, Madrid, Castalia, I, 1969, pág. 55.

10.- Cfr. André Collard, Nueva poesía. Conceptismo, culteranismo en la crifica española, Madrid, Castalia, 1967, págs. 25-27. 


\section{METAMORFOSIS BARROCAS}

ellas, el límite férreo que a la invención impuso la Contrarreforma en los dos países, y la necesidad de apelar al ingenio que combina y no progresa para dar cauce al impulso inventor. Con descubrir paradojas, establecer semejanzas o contrastes, aproximar contrarios y sorprender las mentes con tales juegos hubieron de satisfacerse las aptitudes creadoras de numerosos artistas. Pero a esta interpretación genética del conceptismo se opone el hecho de que también se practicó en países reformados, aunque, por supuesto, no carentes de severa vigilancia sobre el pensamiento.

El hecho es que muchos escritores proceden estableciendo correspondencias, sometiendo su visión a un permanente ir y venir entre las cosas, descubriendo correspondencias y dando así placer al público, inculto o docto según la calidad de los hallazgos, pero agradándole siempre, pues, como el propio Gracián sentencia, «lo que es para los ojos la hermosura, y para los oídos la consonancia, eso es para el entendimiento el conceptos. Éste es, en efecto, la pieza maestra con que se construye todo el organismo barroco, desde el claroscuro pictórico al arte musical de la fuga, pasando, claro es, por todas las invenciones literarias que se realizaron en aquella edad.

La agudeza, o arte de alumbrar conceptos, lo invadió todo; se pensó que constituía la facultad intelectual más alta, hasta el punto de que el jesuita aragonés creyó necesario añadir una disciplina nueva al conjunto de los saberes consagrados, denominándola, precisamente, Agudeza, e identificándola en el título de su famoso tratado como arte de ingenio. Tratado que no es, como tantas veces se ha creído, una Retórica, sino exactamente lo que su autor define: un conjunto de métodos para "realzar el ingenio" sea literaria o no la forma de manifestarse ${ }^{11}$. Y ya sabemos que por ingenio se entendió la cualidad de ser «delgado en la imaginativa», «rico en la elocuencia» y "osadísimo en el ánimo», como Salas Barbadillo definía a su sutil cordobés ${ }^{12}$, lo mismo para urdir patrañas, como éste, que para tramar sublimidades.

Muy pocos escritores se resistieron a esa actividad mental de lanzadera. Sólo aquellos para quienes Horacio siguió siendo modelo, y la llaneza expresiva su objetivo. Un Bartolomé Argensola, por ejemplo, que afirmó: «la agudeza sin límites congoja,/y al rigor con que hiere nos condena” ${ }^{13}$. Por eso, no creo que sea suyo aquel soneto atribuido, en que a Venus, le vaticinan en el templo de Júpiter que su hijo será cosas muy diversas, imposibles de atribuir a un mismo individuo; pero, en efecto,

nacicndo Amor, fue todo verdadcro:

fue ciego, cera, tigre, piedra, fuego,

Argos, guerrero, y todo en un sujeto ${ }^{14}$.

Se trata de una estupenda congregación de conceptos, al hacer que el Amor se corresponda con tantas cosas y tan variadas: un caso de aquellos en que al Rector de Vallehermosa le parecía que el exceso de agudeza acongojaba el ánimo. No parece, pues, posible que sean suyos estos versos.

Porque él, con su hermano Leonardo y pocos más, militó entre quienes resistieron

11.- Cfr. nuestro trabajo "El género literario de El Criticón», Actas de la I Reunión de Filólogos aragoneses, Zaragoza, Institución Fernando el Católico, 1986, págs. 67-70.

12.- El subtil cordobés Pedro de Urdemalas y El gallardo Escarramán (1620), ed. de M. Ch. Andrade, University of North Carolina, 1974, pág. 51.

13.- Ed. cit., II, pág. 365.

14.- Ibid., pág. 685 . 


\section{FERNANDO LÁZARO CARRETER}

al conceptismo. Lo normal fue su ferviente aceptación, popular incluso: su triunfo en los púlpitos y el éxito de poetas chocarreros como Ledesma dan fe de ello.

Sirvió el concepto lo mismo para armar edificios suntuosos como el Polifemo, que para tramar bromas estupendas, como la Fábula de Píramo y Tisbe. Para encrespadas y solemnes piezas oratorias de Paravicino, y para endiablados sueños quevedescos: en ambos extremos, el concepto, ese arte de correspondencias y de metamorfosis, fue prenda de talento inventivo, porque, según decía Gabriel Bocángel, los conceptos «son eternos testigos del entendimiento y ánimo».

Este escritor, absolutamente gongórico, insistió muchas veces en la superioridad del arte conceptuoso. Una de ellas, en el prólogo del Retrato Panegírico del Serenísimo señor Infante Carlos, rectifica a quienes, como, digamos los Argensola, pedían al poema heroico "perpetua gravedad y moderación en galas, locuciones y sentencias», afirmando que las «modernas plumas» desean en el poema «fertilidad de conceptos, travesura en las oraciones, novedad, como no sea extrañeza, en las sentencias...». Y, a propósito del nuevo lenguaje que tanto escandalizaba a algunos, señala que «ya España salió de aquella cortedad ruda con que hablaba, a cuyo moderno brío ya no convienen las sencillas ropas que usaban sus hijos cuando no tenían caudal para los brocados de que hoy visten». «Nuestros poetas antiguos», añade, "sintieron bien, pero hablaron bien sólo entonces, pagando los más la desgracia de haber nacido temprano» ${ }^{15}$. Se trató, ante todo, en la edad barroca, de ser ingenioso o, con voz entonces sinónima, peregrino.

Bocángel fue peregrino, en opinión de sus contemporáneos 16; y para serlo, se hizo cantor de lo grandioso, en clara dependencia ovidiana, con poemas como el extenso dedicado a Leandro y Hero, sujeto a la convicción, dice, de que «no podemos hablar nada grande sino con voz grande» ${ }^{17}$. No hay explicación más pedestre, pero tampoco más verdadera para justificar el alud de cultismos, de latinizaciones que el idioma poético recibió en el seiscientos: imposible alcanzar la grandeza, si no hay grandeza en el lenguaje. Todos proclamaban el ideal de la claridad (a excepción del más sincero, Góngora, que sentía honra de haberse hecho oscuro para los ignorantes), pero la claridad sin grandeza no parecía buena, como Bocángel afirmaba, y «sólo lo culto es bueno en poesía»; es decir, en definitiva, sólo lo recóndito alcanza mérito.

Y aquí es preciso entrar en un viejo problema que ya debería estar superado y que no por aburrido debe dejar de mencionarse al hablar de estas cuestiones. Se trata de las relaciones entre conceptismo y culteranismo, movimientos o estilos o como quiera designárseles que no fueron distinguidos en el siglo XVII, al menos por su más perspicaz escrutador, Gracián, el cual, como es bien sabido, llama a Góngora «culto poeta, cisne en los concentos, águila en los conceptos; en toda especie de agudezas eminente» ${ }^{18}$. Los cultos parecieron una secta a Lope o Quevedo, sólo por su lenguaje; fue ante el empleo de éste donde marcaron sus distancias, no porque el proceso de su ideación fuera diferente. El mismo procedimiento alusivo y elusivo aplica Góngora para llamar a Ganimedes el garzón de Ida, que Quevedo cuando se refiere al remo de las galeras como el hermano de Rómulo.

15.- En la ed. de sus Obras, hecha por Rafael Benítez Claros, Madrid, C.S.I.C., I, 1946, págs. 168-9 y 181.

16.- Su tío Angelo, al menos, le elogiaba su «musa peregrina»; ibid., pág. 20.

17.- Ibid., pág. 13.

18.- Agudeza, discurso V; ed, cit., I, pág. 79. 


\section{METAMORFOSIS BARROCAS}

La oposición entre culteranismo y conceptismo, concebidas como entidades diferentes y enfrentadas en plan de igualdad, aparece en el siglo XVIII, y se atribuye, creo que razonablemente, a José Luis Velázquez, probable acuñador del término conceptismo; pero fue Juan José López de Sedano quien estableció su oposición con el definitivo rigor que después adquiriría, incluso con sus respectivos jefes de filas: Góngora por un lado, y Quevedo por otro. De todos es sabido que Menéndez Pelayo consagró esta distinción historiográfica con su autoridad, al escribir: «Nada más opuesto entre sí que la escuela de Góngora y la escuela de Quevedo, el culteranismo y el conceptismom. Y al señalar como tarea de los historiadores literarios la de «distinguir con claridad ambos impulsos artísticos» ${ }^{19}$. Será Lucien Paul Thomas, en 1911, quien establezca que «los cultistas son, al mismo tiempo conceptistas»; al que seguirá Adolphe Coster, en 1913, afirmando que «no hay cultista que no sea al mismo tiempo conceptista» ${ }^{20}$.

Se trata, pues, de una oposición negada hace muchos años, aunque no con justificaciones terminantes. Alexander Parker y yo mismo las intentamos a la vez, con ocasión del homenaje a Menéndez Pidal que empezó a publicarse en 1950. El trabajo del hispanista británico apareció cuatro años antes que el mío, aunque ambos lo habíamos enviado simultáneamente a los organizadores del homenaje ${ }^{21}$. Afirmaba Parker con toda razón: «Creo que el procedimiento metafórico característico de la época debe denominarse conceptismo, y que será útil emplear la palabra culteranismo para denotar, en primer lugar, la latinización del lenguaje (cultismos, hipérbaton, etc.), y, en segundo lugar, el empleo de metáforas genéricas típicamente gongorinas (nieve, oro, cristal, etc.)... El conceptismo es la base del gongorismo; más todavía, es la base del estilo barroco europeo».

Yo, por mi parte, tras aportar pruebas del conceptismo de Góngora, entendido como arte de metamorfosis y correspondencias, concluía con la necesidad de «reconocer en Góngora y en Quevedo amplias zonas de contacto, y considerar sus respectivos estilos, siquiera en gran parte, como soluciones geniales y personales a problemas expresivos de su época. Problemas y soluciones que podemos acoger bajo la amplia rúbrica de conceptismo... El culteranismo aparece como un movimiento radicado en una base conceptista».

La última revisión extensa que conozco de este problema es el libro de André Collard publicado por la editorial Castalia en $1967^{22}$, curioso amasijo de noticias útiles y confusiones mentales, donde parece combatir la oposición entre culteranos y conceptistas, pero donde curiosamente sólo menciona a Parker de pasada, y a mí me agrupa con Menéndez Pidal, descalificándonos porque ambos postulamos, dice, «por tácita admisión de términos y manejo tradicional de los rótulos 'conceptismo' y 'culteranismo', que en efecto se trata de dos estilos o maneras cultivadas separadamente por autores diversos" ${ }^{23}$. Sistema éste de no enterarse que permite perpetrar libros con la misma gratuidad que las calumnias.

El culteranismo no es sino la solución particular que, para forjar conceptos, es decir, para relacionar cosas, para hacer que se correspondan y hasta lleguen a cambiarse unas

19.- Historia de las Ideas Estéticas, ed. del C.S.I.C., II, Madrid, 1940, págs. 327-8.

20.- Cfr. A. Collard, op. cit., págs. 116-122.

21.- A. A. Parker, «La agudeza en algunos sonetos de Quevedo», Estudios dedicados a Menéndez Pidal, Madrid, C.S.I.C., III, 1952, págs. 345-360; F. Lázaro Carreter, "Sobre la dificultad conceptista», ibid., VI, 1956, págs. 355-386; reproducido en mi libro Estilo barroco y personalidad creadora, Salamanca, Anaya, 1966, págs. 11-59; hay ediciones posteriores.

22.- Cit. en la nota 10 .

23.- Op. cit., pág. 112. 


\section{FERNANDO LÁZARO CARRETER}

en otras, apela a saberes remotos, con frecuencia mitológicos, y a expresiones lingüísticas (no sólo palabras) de origen latino. La dificultad aneja al pensar conceptista se ve multiplicada aquí por lo enigmático que, incluso para lectores cultivados, imponían tales alardes de saber: de ahí la actividad de los comentaristas de Góngora, que son como respuestas que algunos eruditos dan al arte del cordobés, al sentirlo como un desafío. Un humanista como Pedro de Valencia no duda en confesar al poeta que, muchas veces, no lo entiende.

Pero es sólo esto, la oscuridad, término empleado en las polémicas gongorinas que no hay necesidad de evitar, lo que diferencia a los culteranos en el seno del conceptismo común a una gran parte de nuestros escritores barrocos. Y es esa solución ostentosa, la que se censuró a sus practicantes. Una solución que don Luis no vaciló en amparar con el nombre de Ovidio, en su famosa carta en defensa de las Soleckades. Recuérdese cómo, sosteniendo la utilidad de la poesía oscura, señalaba la muy importante de «avivar el ingeniom, e invocaba el libro de las Transformaciones como admirable modelo de oscuridad útil ${ }^{24}$.

Y volvemos, ya hacia el final, al gran poeta latino y a sus Metamorfosis como inspiradores máximos del Barroco. Dos grandes poemas de Góngora les son directamente deudores: el Polifemo y la Fábula de Píramo y Tỉsbe. El tercero de los poemas grandes, las Soledades, le debe mucho, en puntos que me parece no ha considerado aún la crítica gongorina; pero no es ese ahora nuestro asunto. Los otros dos siguen linealmente los respectivos relatos ovidianos, aunque en sentido diametralmente opuesto: hacia la exaltación entusiasta del mito polifémico el primero, y hacia la burla del amor que se profesaron Tisbe y Píramo, la Fábula. No estoy muy seguro, sin embargo de que Acis y Galatea merezcan a Góngora mayor complacencia que los amantes babilonios. Me parece percibir a lo largo del Polifemo una ironía latente hacia el mito, una burla soterrada del poeta, tanto más notable cuanto mayores magnificencias de contenido y de forma exhibe. Si la octava 36 significa lo que creo - y no me atrevo a exponer-, el cordobés, dando muestra de su talante infinitamente burlón, habría escrito los versos cultos más obscenos de nuestra literatura 25 .

En mi trabajo de 1956, señalé algunos de los procedimientos retóricos que el conceptismo aplicó más insistentemente para establecer correspondencia entre las cosas. El más simple, obviamente, es la comparación: Góngora compara aśl la desembocadura del río Luco, en su poema de la toma de Larache, «Desta, pues, siempre abierta, siempre hiante/y siempre armada boca,/cual dos colmillos, de una y de otra roca...). Mucho más compleja es la metáfora, que nombra dos cosas semejantes con el nombre de una sola de ellas, y que hace de las olas de ese mismo río escamas de cristal. Pero muchas veces las correspondencias se establecen por intermedio de los vocablos. Así, la paronomasia ( $N u b e s$ son y no naves», escribe también Góngora); el juego de palabras que tanto practica

24.- Obras de Góngora, ed. de J. e 1. Millé, Madrid, Aguilar, s. a., pág. 956.

25.- En la rústica greña yace oculto/el áspid, del intonso prado ameno, /antes que del peinado jardín culto/en el lascivo, regalado seno:/en lo viril desata de su vulto/lo más dulce el amor, de su veneno;/bébelo Galatea, y da otro paso/por apurarle la ponzoña al vaso. Dámaso Alonso lo interpreta así, en Góngora y el Polifemo, Madrid, Gredos, 5.a ed., 1967, pág. 186: «La víbora yace oculta en rústica maraña del ameno prado que nadie siega, mejor que en el regalado seno de un jardín exquisitamente cultivado. Así, en la descuidada virilidad del rostro de Acis, ha entremezclado o disimulado el Amor lo más dulce de su veneno. Galatea lo está bebiendo ya con los ojos, y sin ser dueña de sí, da aún otro paso y se acerca más a Acis, para mirarle mejor, para apurar hasta el fin aquel vaso de amorosa ponzoña). 


\section{METAMORFOSIS BARROCAS}

(«Tenedme, aunque es otoño, ruiseñores/ya que llevar no puedo ruicriados»); el calambur ("Que, pues sus pies, son de elegía»); la disociación de vocablos (Di, Ana, eras Diana); y, por fin, la dilogía o doble sentido en que se emplean un vocablo o una expresión; ejemplo eminente, lo que Dorotea dice en el Quijote (I, 28): «(Fernando) apretóme más entre sus brazos, de los cuales jamás me había dejado, y con esto, y con volverse a salir del aposento mi doncella, yo dejé de serlon.

Góngora complica este, en definitiva, sencillo cuadro de figuras tradicionales, con otros modos muy característicos de crear conceptos. Así, la fórmula no $B$ sino $A$ y similares, estudiadas por Dámaso Alonso, que niegan un término y afirman otro, y que ahora podemos interpretar mejor como un propósito de forzar correspondencia entre ellos, es decir, para acuñar conceptos. Cuando en el Polifemo se lee «... húmidas centellas,/si no ardientes aljófares sudando,/llegó Acis", hay una primera aproximación metafórica de las gotas de sudor a las centellas; y, enseguida, con la fórmula $A$, si no $B$, se acercan las centellas a los aljófares, sobreañadiendo un concepto al anterior.

Pero esta técnica conceptual se manifiesta por modos muy variados. Así, mediante la disyunción («... el Lilibeo,/bóveda o de las fraguas de Vulcano/o tumba de los huesos de Tifeo»); aquellos dos peñascos extremos de la desembocadura del Luco que vimos, se transformarán enseguida disyuntivamente: «África (o ya sean cuernos de su Luna,/o ya de su elefante sean colmillos)/ofrece al gran Filipo los castillos». Ambas rocas se han metamorfoseado primero en colmillos, despućs cn cucrnos de la Mcdia Luna sarraccna, $y$, por fin, titubeando el poeta, no decidiéndose por ninguna de esas dos identidades, han regresado a ser colmillos, sometiendo a la mente del lector a inseguridad y vaivén, a una visión caleidoscópica y transformista.

Hace años que dediqué alguna atención a la Fábula de Píramo y Tisbe ${ }^{26}$, el poema que, según José Pellicer y Cristóbal Salazar Mardones, estimó Gongora más, y que es el último de sus esfuerzos poéticos de más extensión. Expliqué algunos de sus pasajes, insuficientemente o mal interpretados, me parece, por sus comentaristas, porque son de extrema dificultad. Se trata, como sabemos, de la primera fábula mitológica burlesca escrita en España, mezcla extraordinaria de sublimidades y bellaquerías urdidas sobre el texto de Ovidio, en la cual el poeta extrema con dominio pleno y definitivo los recursos que caracterizan su segunda época. Creo que avanzar con el examen de algún trecho más en el esclarecimiento de tan estupendo poema, puede ser un modo práctico de concluir una meditación sobre las metamorfosis barrocas. Sean estos pocos versos:

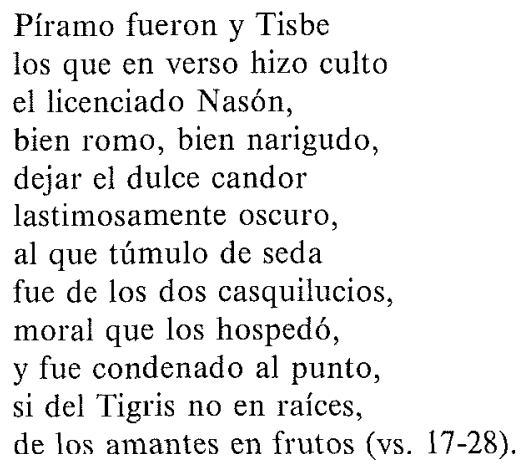

26.- En Estilo barroco..., págs. 61-108. 
Con ellos, tras unas pullas contra sus detractores, empieza el relato, a los que provoca enseguida con uno de los rasgos que más le fueron reprochados: el hipérbaton. En éste, los dos sujetos, Píramo y Tisbe, quedan separados por el verbo plural, que, al venir tras el primero de esos en singular, produce un choque sintáctico de extraordinaria violencia: Píramo fueron... Era, insisto, un desafío a los que acababa de llamar «tribunos del vulgo». Pero hay otro hipérbaton en el segundo de estos versos: los que en verso hizo culto, en que hizo se entromete demasiado pronto, pues no asumirá su función de auxiliar factitivo hasta tres versos después: "A Píramo y Tisbe, el licenciado Nasón hizo dejar el dulce candor lastimosamente oscuro». Y aún vendrá otro hipérbaton más descoyuntado:
al que túmulo de seda
fue de los dos casquilucios, moral que los hospedó,

en el que debe reconstruirsc cste orden: Nasón 'hizo dejar su dulce candor al moral que los hospedó, los cobijó bajo sus ramas, y se convirtió para ellos en túmulo de seda, porque allí murieron, con lo cual sus frutos perdieron para siempre su candor o blancura, al volverlos lastimosamente oscuros, morados para siempre, la sangre de los amantes que brotó hasta ellos.

Pero no es el hipérbaton un rasgo conceptista, sino un añadido culterano al conceptismo. Veamos algunos conceptos de estos versos. Obsérvese que Góngora hace a Ovidio Nasón responsable de la oscuridad de las moras por haber escrito aquella peregrina historia en verso culto. La identificación de lo culto con lo oscuro se había hecho habitual en las polémicas gongorinas dos o tres años después de haberse difundido las Soledades ${ }^{27}$. Se recordará la sarcástica broma de Quevedo en La hora de todos: "Estaba un poeta en un corrillo leyendo una canción cultísima..., y a la oscuridad de la obra... acudieron lechuzas y murciélagos» ${ }^{28}$.

El concepto gongorino, como vemos, compartido por Quevedo, consiste aquí en algo tan sencillo, como pasar de la oscuridad metafórica a la real, a la capacidad de unos versos cultos para tornar oscuros unos frutos que, antes, eran claros de color.

Toda la fábula es degradadora, por toda ella circula aquella especie de venganza que, como según decíamos, se toman muchos escritores barrocos contra las altas hazañas y los grandes prestigios, introduciendo elementos llamémosles «naturalistas» que permiten controlar irónicamente todas las desmesuras al establecer distancias frente a ellos. Aquí es el indiscutible Ovidio Nasón, tan admirado por Góngora, quien recibe un arañazo de su admirador, al llamarlo «licenciado». No sin motivo, pues, como dice Salazar Mardones en su comentario, «a todo abogado o hombre que trata de leyes, le llamamos en este tiempo licenciado. Y como Ovidio fue juez y abogó por algunos reos, con justa razón le dio (Góngora) este grado» (fol. 12 oㅡ). Pero que esto era una broma no escapó ni al ingenuo comentarista. El poeta trivializa al augusto maestro latino, se libera del peso de tanta genialidad, $y$, de paso, justifica la imagen jurídica final.

Otro concepto degradador, mediante el recurso a la disyunción, hay en hacer al licenciado Nasón «bien romo, bien narigudo», aprovechando que naso, mote de la familia

27.- Cfr, Lucien P. Thomas, Le lyrisme et la préciosité cultiste en Espagne, Halle-París, 1909, págs. 164-9

28.- Ed. cit., pág. 293. 


\section{METAMORFOSIS BARROCAS}

de Ovidio, significa 'nariz'; un Nasón sería, pues, un narigudo; pero al poeta le da igual, y si lo llama así es para oponerle chistosamente el adjetivo romo.

La imagen del moral como túmulo es sugerida por las Metamorfosis, donde se dice: «Y tú, árbol, que con tus ramas das sombra ahora al pobre cuerpo de uno solo, pero pronto la darás a los de los dos...) ${ }^{29}$. Era, pues, un túmulo; pero precisamente de seda, es decir, por un lado, suntuoso y rico; pero por otro - un significar a dos caras estrictamente conceptista-, porque las hojas del moral son el alimento de los gusanos de seda. La misma asociación conceptuosa del moral con los amantes de Babilonia y la seda, aparece en el soneto que Góngora dedicó, en 1593, a don Cristóbal de Mora:

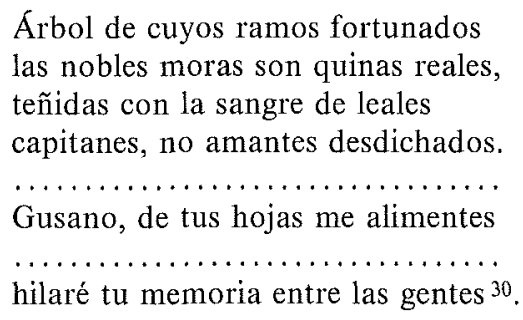

Y llegamos a los tres versos últimos de esta breve tirada:

y fue condenado al punto, si del Tigris no en raíces, de los amantes en frutos.

Se degrada el sentido de la fábula, que explicaba la metamorfosis vegetal y ennoblecía al moral como testigo de la muerte que, por amor heroico, padecieron Píramo y Tisbe, convirtiéndolo en un hospedador, en el encubridor de aquella locura de dos casquilucios. Por lo cual fue castigado, no en raíces (el Tigre no lo arrancó), pero sí en frutos. Es un nuevo concepto fundado en la fórmula forense: "Condenar en raíces y frutos», es decir, mediante la incautación o destrucción de los bienes raíces, y de los frutos y beneficios obtenidos con ellos.

Toda la fábula es así: el magno relato metamorfoseador de Ovidio se transforma, a su vez, en la crónica burlesca, sangrienta a veces, del capricho de dos casquilucios, un botarate y una tontaina, víctimas de su incomprensible emperramiento en amarse. Es, y concluyo reiterándolo, el zarpazo que, en el siglo barroco, da el sentido de la realidad a las magnificencias espectaculares y a los prestigios inmaculados y dogmáticamente intangibles.

29.- At tu, quae ramis arbor miserabile corpus/nunc tegis unius, mox es tectura duorum. (IV. 158159).

30.- Ed. cit., pág. 256. 